\title{
Current growth, fat reserves and somatic condition of juvenile Baltic herring (Clupea harengus membras) reared in different salinities
}

\author{
Marjut Rajasilta $\cdot$ Päivi Laine $\cdot$ Jorma Paranko
}

Received: 4 March 2009/Revised: 25 March 2010/Accepted: 9 April 2010/Published online: 24 April 2010

(C) Springer-Verlag and AWI 2010

\begin{abstract}
We studied the effect of salinity on growth, fat reserves and condition of the Baltic herring (Clupea harengus membras) juveniles in order to determine their optimum salinity. About 5 months old fish were reared in four salinities $(5.7,8,12$ and $15 \mathrm{psu})$ over a period of 1.5 months in constant temperature $\left(+6^{\circ} \mathrm{C}\right)$ and photoperiod (light:dark $=12 \mathrm{~h}: 12 \mathrm{~h}$ ). Uptake of radioactively labelled glycine $\left({ }^{14} \mathrm{C}\right.$-glycine $)$ by the scales was used as an indicator of growth rate. The amount of mesenteric fat varied among individuals, but fish kept in 12 psu had significantly more fat in their body cavity and also their somatic condition was better $(P<0.05)$ than in juveniles kept in the other salinities. Incorporation of ${ }^{14} \mathrm{C}$-glycine by the scales was dependent not only on salinity, but also on the method of scale sampling. Part of the scales sampled was non-growing and therefore unsuitable for the analysis of growth. Using the growing scales in the analysis, the current growth rate of herring juveniles was highest in salinities of 8 and 12 psu. Fat reserves, somatic condition and growth rate suggested that Baltic herring juveniles have their optimum salinity in $8-12 \mathrm{psu}$, which is
\end{abstract}

Communicated by Arne Malzahn.

M. Rajasilta $(\square) \cdot$ P. Laine

Archipelago Research Institute,

University of Turku, 20014 Turku, Finland

e-mail: marjut.rajasilta@utu.fi

P. Laine

e-mail: paivi.laine@utu.fi

J. Paranko

Department of Cell Biology and Anatomy,

Institute of Biomedicine,

University of Turku, 20014 Turku, Finland

e-mail: paranko@utu.fi somewhat higher than the salinity in most of the nursery grounds in the Baltic Sea.

Keywords Baltic herring - Juveniles - Salinity ·

Condition · Growth $\cdot$ Scales

\section{Introduction}

Herring (Clupea harengus membras) is a dominant planktivore and a key species of the Baltic Sea ecosystem (Rudstam et al. 1994; Parmanne et al. 1994). High abundance and wide distribution give the species an important position also in the fisheries and fish processing industry. The Baltic stock is divided into several subunits for the management purposes (e.g., ICES 2008), but no genetic differentiation has been found among them so far (Jörgensen et al. 2005).

In the Baltic Sea, herring lives in salinity conditions, which deviate substantially from those in the neighbouring North Sea and Atlantic Ocean. According to recent genetic studies, salinity is the major isolating barrier between the herring stocks in the North Sea and the Baltic Sea (Jörgensen et al. 2005; Bekkevold et al. 2005). Adult herring tolerate a wide salinity range (Holliday and Blaxter 1961) and live even in lakes (Neb 1970; Hognestad 1994), but to reproduce successfully herring requires saline water. This suggests that salinity in the spawning area plays a major role in the differentiation of the Atlantic and Baltic stocks.

The Baltic herring reproduces in salinities of $2-3$ to 8-9 psu, depending on the distance of each spawning area from the Danish straits, which form the only route for the Atlantic water to enter the Baltic Sea (Fig. 1). Griffin et al. (1998) showed experimentally that eggs of the Baltic herring are fertilised in a wide salinity range (4-32 psu), but 


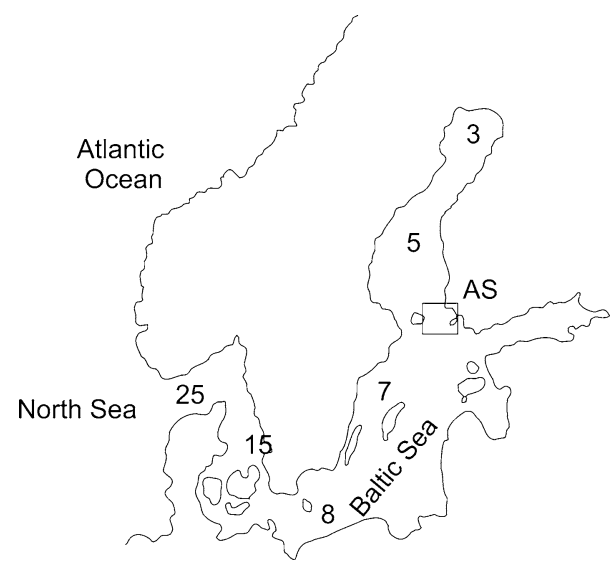

Fig. 1 The Baltic Sea and the herring sampling area in the Archipelago Sea (AS), south-western Finland. The numbers indicate the average surface salinity (psu) in different areas [salinity values according to Segerstråle (1957) and Fonselius and Valderrama (2003)]

the fertilisation success is highest in 8 psu. This corresponds to the salinity conditions at water surface in the southern Baltic Sea (e.g., Fonselius and Valderrama 2003). After fertilisation, embryonic development seems to be normal at salinities of 5-20 psu (Ojaveer 1981), but below 5 psu, development is less successful (Klinkhardt 1984). The salinity optimum or tolerance at later embryonic stages or in larvae and juveniles has not been studied. Therefore, it is not known, which phase in ontogeny is the most critical one in the adaptation of herring to Baltic salinity.

In the present paper, we examined the influence of water salinity on the fat reserves, somatic condition and growth of the Baltic herring juveniles experimentally. These parameters have been determined in euryhaline fish species, in order to find out their optimum salinity at juvenile or adult stages (e.g., Hettler 1976; Boeuf et al. 1999; Jarvis et al. 2001; Imsland et al. 2001, 2003). Experimental studies with adult or juvenile Baltic herring have not been made previously (Westin and Aneer 1987), partly because the herring is highly sensitive to handling stress and difficult to keep in captivity for long periods (Blaxter and Holliday 1963). This puts extra demands on the experimental procedure and treatment of fish before and during the experiment. E.g., fish handling has to be avoided as much as possible, because it increases mortality in the experiments due to loss of scales (Holliday and Blaxter 1961). In order to minimise the disturbances during and before the experiment, we therefore determined the growth rate from fish scales in vitro using a method described by Goolish and Adelman (1983). The method has not been applied in the studies of juvenile fish previously, and further development of the method was therefore required, especially concerning the sampling of scales for the determination of the growth rate.

\section{Materials and methods}

\section{Experimental procedure}

Herring juveniles were caught in July in the Archipelago Sea, northern Baltic (Fig. 1), and reared until autumn in net pens (mesh size $4 \mathrm{~mm}$ ) in the sea. Fish were fed daily with dry pellets (Skretting Nutra HP), but they were also able to feed on natural zooplankton that entered the walls of the net pens. In October, fish were moved to a large tank in the laboratory hall. They were kept in ambient temperature and salinity and fed daily until the start of the experiment. During the above acclimation period, fish grew so that their scales became large enough for the measurements.

After the acclimation period, a random sample of ca 200 individuals was taken, divided in four groups and placed into the experimental tanks. The number of fish was estimated by eye, but the goal was to have about $40-50$ fish in each tank. At this phase, fish were approximately 5 months old. Square tanks with rounded edges (area $1 \mathrm{~m}^{2}$; height $0.5 \mathrm{~m}$; water volume $300 \mathrm{l}$ ) were used. Water was taken from the sea nearby, where salinity was 5.7 psu at the time of the experiment. The ambient sea water was taken as the lowest salinity in the experiments, and three higher salinities $(8,12$ and $15 \mathrm{psu})$ were obtained by adding coarse sea salt $\left(\mathrm{Jozo}^{\circledR}\right)$ to the ambient sea water. The salinities thus matched the salinity gradient at sea surface from the Archipelago Sea to the Danish Sounds (Fig. 1). This represents the area, where Baltic herring is known to spawn (e.g., Haegele and Schweigert 1985) and the adjacent waters where the spawners of the south-western herring population live as adults (Jönsson and Biester 1981; Aro 1989). The aquarium hall received daylight from the windows, but also electric light was used for lightning (12 h light:12 $\mathrm{h}$ dark). Water temperature in the tanks was kept $+6^{\circ} \mathrm{C}$ over the experiment. This is the long-time average at 20 metre's depth in late autumn in the study area (statistics of the Archipelago Research Station, University of Turku). All tanks were well aerated with aquarium pumps. Fish were fed ad libitum daily with dry pellets, which they already were used to feed on. In the daily rearing routines, fish behaviour was recorded by eye; part of the tank water (ca 10\% of the total volume) was changed and salinity and oxygen saturation were measured using a salinometer equipped with an oxygen detector. Dead individuals were removed from the tanks and counted. At the end of the experiment, the initial fish density was calculated by adding the number of the dead with the number of the remaining fish in the tank. The duration of the experiment was 1.5 months (December 16-February 4).

At the end of the experiment fish $(n=10$ in each salinity) were anesthetised with tricaine methanesulfonate salt (MS-222). A sample of scales was removed 
immediately (see below), after which fish were killed and their total length (in $\mathrm{mm}$ ) and total weight (in g) was determined. The alimentary canal was opened to see whether fish had taken food or not, and the amount of visceral fat (Fat index; FI) was estimated visually using a relative scale of $0-3$ ( $0=$ no fat; $1-2=$ increasing amount of fat around the intestine; 3 = rich deposits of fat around the intestine). Condition factor (CF) was calculated as $\mathrm{CF}=$ total weight/total length ${ }^{3}$ (Tesch 1971).

Measurement of the growth

The simplest way to measure the growth of fish is to determine their size in the beginning and end of the study period. However, this could not be done with herring juveniles, as measurement of the original length and weight requires handling of fish, which increases their mortality. For this reason, we determined growth in vitro using the method described by Goolish and Adelman (1983). Principally, the growth of scales or other body tissues follows the general growth pattern of an individual. Accordingly, the protein synthesis in these tissues indicates the rate of protein synthesis in fish body. Hence, the current growth rate can be measured as the uptake of radioactively labelled amino acids by scales or other body tissues (Ottaway and Simkiss 1977; Ottaway 1978; Adelman 1987; Busacker and Adelman 1987; Negatu and Meier 1993, 1995).

Earlier studies have shown that radioactivity in scales is dependent on the size of the scales (Adelman 1987). As herring juveniles have small scales, the total scale area in a sample was increased by collecting several tens of scales from each fish. The scales were removed from the upper caudal part of the fish after they were anesthetised (No. of fish $=10$ in each salinity). This is the body area where otolith and scale ages are equal in young (age 2-4 years) Baltic herring (Eklund 1999). The scales of each fish were divided between four Eppendorf tubes containing physiological teleost saline buffered with HEPES ( $\mathrm{pH} 7.5)$ and freshly added unlabelled glycine $(3.2 \mathrm{mg} / \mathrm{ml})$. In three tubes, $2 \mu \mathrm{l}{ }^{14} \mathrm{C}$-glycine with specific activity of $430 \mathrm{mCi} /$ mmol (Amersham) was added; one was left without radiolabel as a control. The tubes ( 3 radiolabelled, 1 control/fish) were incubated in a water bath at $+25^{\circ} \mathrm{C}$ for $120 \mathrm{~min}$, after which the scales were washed thoroughly with saline buffer. After this, fish from each salinity were randomly divided into two groups (No. of fish $=5$ in both) and the size of their scales was measured using two alternative methods. In the first group (method M1), scales ( $n=10 /$ tube) were taken in a random order, and in the second one (method M2), scales of uniform size ( $n=10 /$ tube) were selected, as suggested by Busacker and Adelman (1987). The area of the scales was measured individually under a dissecting microscope by comparing the scale with a set of circles having a known area (from 1 to $15 \mathrm{~mm}^{2 \text {; }}$ precision $0.5 \mathrm{~mm}^{2}$ ). After measurement, scales were rinsed with saline, transferred to clean tubes and digested in $200 \mu \mathrm{l}$ tissue solubiliser (Luma Solve), incubated for $12 \mathrm{~h}$ at $+55^{\circ} \mathrm{C}$ and homogenised manually in a 5-ml volume glass homogeniser. After adding $1 \mathrm{ml}$ scintillation medium (OptiPhase Supermix, Wallac, Finland), radioactivity in the scale samples was recorded with the Microbeta Plus Liquid Scintillation Counter (Wallac, Finland). Counting time was $2 \mathrm{~min}$. The scale growth was expressed as a number of counts $/ \mathrm{mm}^{2}$.

\section{Statistical analyses}

Normal distribution of all parameters was studied graphically, and the test was chosen accordingly. Fish body length, weight and condition in different salinities were compared with non-parametric analysis of variance (Kruskall-Wallis -test). In the correlation analyses, Spearman rank correlation test was used (correlation coefficient $r_{\mathrm{s}}$ ). The effect of salinity on the amount of visceral fat was studied with Kruskall-Wallis test and the pairwise comparisons between the salinities were performed with MannWhitney $U$-test. This test was also used in the comparison of the scale size between the scale sampling methods M1 and M2. The effect of salinity on the growth rate (No. of counts/ area of scales in $\mathrm{mm}^{2}$; ln-transformed values) was tested with analysis of variance. The growth rate was taken as a mean value of the three replicates of each fish. Pairwise comparisons were made with Tukey's test, and homoscedasticity of variances was tested with Levene's test. In all tests, the SPSS statistical package was used (SPSS Inc. 2005; version 14.0).

\section{Results}

Scale growth in different salinities

The analysis of scale size revealed that the scale sampling method M1 (scales taken in random: mean scale area $=5.1 \mathrm{~mm}^{2} ; N=60$; Fig. 2a) resulted in a collection of significantly larger $(P<0.001)$ scales than the sampling method M2 (scales of equal size selected: mean scale area $=3.4 \mathrm{~mm}^{2} ; N=60$ ). Radioactivity and scale area had a significant and positive correlation in all salinities (5.7 psu: $\quad r_{\mathrm{s}}=0.733 ; \quad P<0.01 ; \quad 8$ psu: $\quad r_{\mathrm{s}}=0.724$; $P<0.01 ; 12$ psu: $r_{\mathrm{s}}=0.733 ; \quad P<0.01$ and 15 psu: $\left.r_{\mathrm{s}}=0.441 ; P<0.01\right)$, but this was mainly due to the results obtained by scale sampling method $\mathrm{M} 1$. In method M2, the radioactivity counts remained at the level of control scales in all salinities (Fig. 2b). Based on this result, the scales of method M2 were excluded from the growth 
(a)

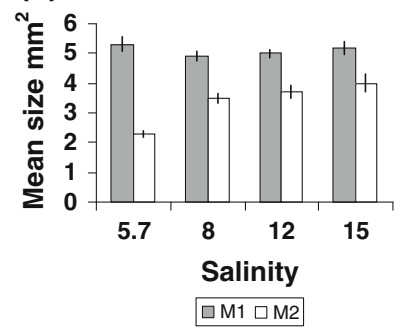

(b)

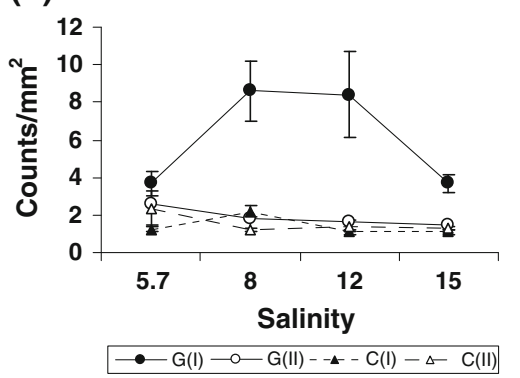

Fig. 2 a Size of scales (mean $\mathrm{mm}^{2} \pm \mathrm{SE}$ in different salinities) collected using two different sampling methods (M1 and M2; see text). b Growth rate (mean radioactivity counts $/ \mathrm{mm}^{2} \pm \mathrm{SE}$ ) of herring juveniles in different salinities. $\mathrm{G}(\mathrm{I})=$ growth rate of scales according to scale sampling method $\mathrm{M} 1 ; \mathrm{G}(\mathrm{II})=$ growth rate according to scale sampling method M2; C(I) and C(II) = counts of radioactivity in control scales in the two methods M1 and M2, respectively. See Table 1 for the values of $P$ in pairwise comparisons of $\mathrm{G}(\mathrm{I})$

analysis and only those obtained with the scale sampling method M1 were used.

The scale growth measured as the amount of incorporated radioactive glycine (No. of counts $/ \mathrm{mm}^{2}$ ) increased with increasing salinity, but not in a linear way (Fig. 2b). The highest values were found at salinities of 8 and $12 \mathrm{psu}$ (mean $=8.8$ and 8.4 counts $/ \mathrm{mm}^{2}$, respectively) but in salinities of 5.7 and 15 psu the values were clearly lower (mean $=3.7$ and 3.7 counts $/ \mathrm{mm}^{2}$, respectively). According to ANOVA, salinity explained $50.6 \%$ of the variation of scale growth and the effect of salinity was significant $(\mathrm{F} 3,16=5.464 ; P<0.01)$. Pairwise comparisons showed that growth rate was significantly higher in salinities of 8 and 12 psu than in 5.7 and 15 psu (Table 1).

Fat reserves, somatic condition and mortality

At start, density of fish varied slightly between the tanks, because the number of fish could only be estimated by eye when they were transferred into the test tanks, in order to avoid handling stress. Different mortality rates among the tanks changed the situation further so that the highest density was found in the highest salinity ( $15 \mathrm{psu})$ at the end of the experiment. No mortality occurred during the first
Table 1 Values of $P$ in pairwise comparisons of the growth rate (G(I); Tukey's test) in salinities of 5.7 (ambient), 8, 12 and $15 \mathrm{psu}$; for the growth rate, see Fig. $2 b$

\begin{tabular}{llll}
\hline Salinity (psu) & & & \\
\hline & 5.7 & 8 & 12 \\
\hline 8 & 0.03 & & \\
12 & 0.06 & 0.98 & \\
15 & 0.99 & 0.03 & 0.08 \\
\hline
\end{tabular}
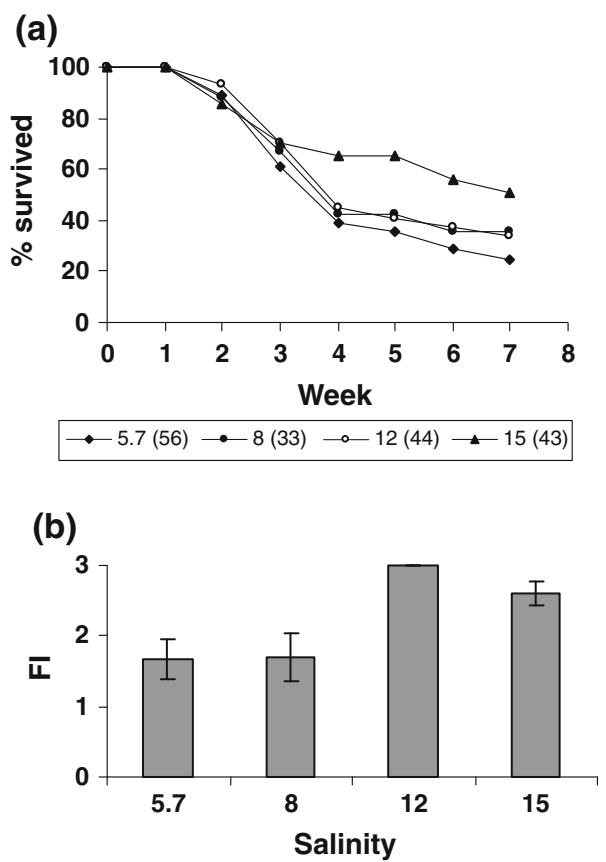

Fig. 3 a Survival of herring juveniles in different salinities (5.7, 8, 12 and $15 \mathrm{psu}$ ) during the experiment. The lines indicate the percentage of fish surviving (original No. of fish is shown in parenthesis); b Mean amount of visceral fat (FI; mean $\pm \mathrm{SE}$ ) in herring juveniles in different salinities. $n=10$ in each salinity. All pairwise comparisons of FI are significant at level $P<0.05$, except in salinities 5.7 and 8 $(P>0.10)$. Note that in $12 \mathrm{psu}$, all fish had FI $=3$

week of the experiment, and the survival rates were quite equal until week 3 . Between weeks 3 and 4, mortality increased rapidly in all other salinities except the highest one (Fig. 3a). In 15 psu, $51 \%$ of fish of the original number were left at the end of the experiment, while the values in other salinities ranged from $25 \%$ in 5.7 psu to $34 \%$ in 12 psu.

In all test tanks fish were feeding, as indicated by the contents of their alimentary canal. Of the 40 fish investigated, only two had an empty stomach at the end of the experiment. All fish also had fat in their body cavity (Fig. 3b). However, the fat index (FI) indicated significant differences in the fat reserves of fish in different salinities $(P=0.001)$. In low salinities (5.7 and 8 psu), majority of 


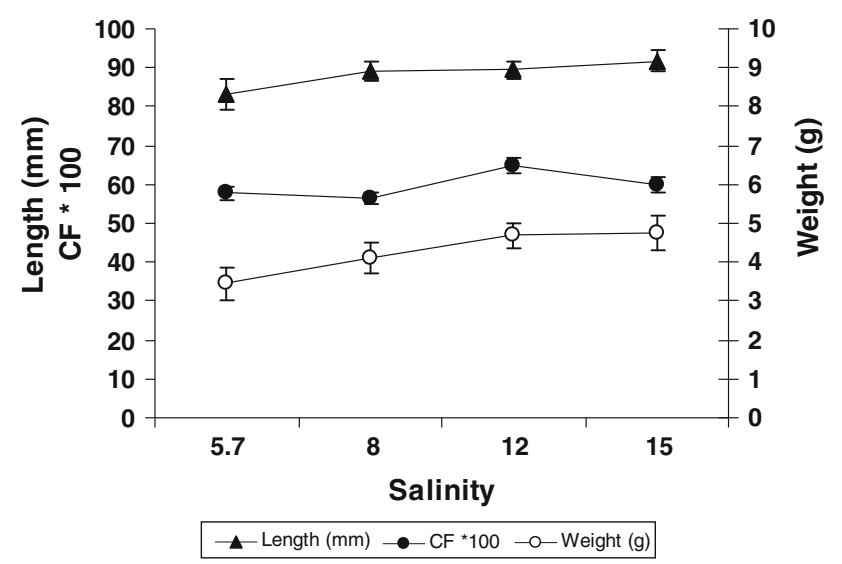

Fig. 4 Mean length (mm), weight (g) and condition factor (CF *100) $( \pm \mathrm{SE})$ of herring juveniles in different salinities at the end of the experiment. See Table 2 for the values of $P$ in pairwise comparisons of condition factor; $n=10$ in each salinity

fish had a small amount of fat $(\mathrm{FI}=1)$ on the surface of the intestine and rich deposits $(\mathrm{FI}=3)$ were found only in few individuals. In 12 psu, all fish had rich fat deposits in the body cavity (mean FI $=3$ ). The pairwise comparisons indicated that the mean FI was significantly higher in 12 psu than in any other salinities (for the $P$-values; see Fig. 3b).

Total length, weight and condition of the fish also varied among the salinities (Fig. 4). At the end of the experiment, the largest fish were found in salinity of $15 \mathrm{psu}$ (mean $=92 \mathrm{~mm} ; n=10)$ and smallest in the salinity of $5.7 \mathrm{psu}$ (mean $=83 \mathrm{~mm} ; n=10$ ). However, variation among the test groups was high and the differences in mean length and weight were insignificant (length: $P>0.10$; weight: $P=0.10)$. Instead, there was a significant difference in the condition factor among salinities $(P=0.015)$. Pairwise comparisons showed that condition factor of fish kept in salinity of 12 psu was significantly higher than that of fish in all other salinities (Table 2).

\section{Discussion}

Uptake of radiolabelled glycine has been used in the studies of growth of adult fish (Goolish and Adelman 1983; Busacker and Adelman 1987), but not in studies of fish juveniles, as far as we know. According to our results, a major problem in using this method is the sampling of scales as this clearly affected the growth values obtained with herring juveniles. As it was not known, which scales best represent the growth process of juvenile Baltic herring, the scales were removed from the area, which has been used in the studies of age and growth in the herring previously. Eklund (1999) determined the age of the Baltic herring from scales and otoliths and found that in young
Table 2 Values of $P$ in pairwise comparisons of condition factor (Mann-Whitney $U$-test) in salinities of 5.7 (ambient), 8, 12 and 15 psu. No. of fish $=10$ in each salinity; values of CF are shown in Fig. 4

\begin{tabular}{llll}
\hline Salinity (psu) & & & \\
\hline & 5.7 & 8 & 12 \\
\hline 8 & 0.47 & & \\
12 & 0.01 & 0.00 & \\
15 & 0.45 & 0.13 & 0.03 \\
\hline
\end{tabular}

fish (age 2-4 years) the otolith age and scale age are equal, if scales are removed from the upper caudal part of the fish. However, in our experiment this did not guarantee that all scales sampled were suitable for the growth analysis.

In juvenile fish, the scales are thin and small and the counts of radioactivity probably too low to be detected reliably, if at all, in single scales. For this reason, we increased the total area of the scales tenfold, by combining a set of ten scales from each fish into a sample. This procedure was clearly necessary for the detection of radioactivity, but it brought about another problem: how to select the scales, when there is some variation in size even among the scales of an individual fish?

The scale sampling method M2, i.e., choosing scales of uniform size (Busacker and Adelman 1987), resulted in a significantly smaller scale size than the random sampling used in method M1. The obvious reason was that small scales were more numerous than big ones and they were selected because of their higher frequency. Small scale size, in turn, may have been a result of degeneration of the scales (e.g., Tesch 1971), which takes place in given physiological conditions. Scales are rich in calcium, which is needed especially at times of active growth. If necessary, fish can absorb the scale material, use it for the formation of bones and other body structures, and rebuild the scales later, when the conditions have changed. So, in addition that scales protect the fish body, they form a calcium reservoir, which fish can utilise according to their physiological condition (Kapoor and Khanna 2004). Most likely, scales are not a stable structure particularly in fish juveniles, which grow fast but have no large depots of calcium required in the growth. The dynamic character of scales should thus be taken into account, when collecting them for the growth analysis of fish juveniles. According to our results, $\geq 10$ scales collected in random and combined into a sample diminishes this problem, as the probability of getting growing scales increases in this way.

The size of the scales obtained using method M1 was equal in different salinity groups (Fig. 2a), but the uptake of ${ }^{14} \mathrm{C}$-glycine was significantly more active in 8 and 12 psu than in the two other salinities (Fig. 2b). However, 
also in these (5.7 and $15 \mathrm{psu}$ ) incorporation of radioactive glycine was increased compared with the control scales, indicating that some growth took place in these salinities as well. To conclude, measurement of the growth rate using the present method seems appropriate in the studies of fish juveniles, as long as the problems in sampling of scales are taken into account.

Salinity affected significantly also the accumulation of fat in the body cavity during the experiment. At the end of it, fish in the highest salinities (12 and 15 psu) had significantly more mesenteric fat than fish in lower salinities (5.7 and 8 psu). There were differences among individual fish in all salinities except 12 psu, where all fish had rich fat deposits and their physical condition was significantly better than in other salinities. The differences in the fat reserves and fish condition may indicate an optimum of feed conversion rate (Jarvis et al. 2001) in salinity of 12 psu or close to it. This could be linked to the lipid metabolism, which can be altered by salinity through enzymatic activity (Cordier et al. 2002).

Sensitivity to handling stress causes high mortality in herring kept in captivity (Blaxter and Holliday 1963). This is the obvious reason why no long-term experiments have been done with adult or juvenile Baltic herring previously. In our study, the expected high stress-induced mortality, together with the limited number of experimental fish, prohibited the use of replicate experimental tanks. Also, the study had to be interrupted because of fish mortality, which occurred in all test tanks irrespective of the salinity. In the first place, mortality indicates the low tolerance of the herring of life in captivity. In fish kept in non-optimal salinity conditions, the reason for high mortality is usually the difficulty of maintaining ionic balance, which takes place mainly through the gill epithelium (Evans 1980; 1993). That fish mortality was lowest in salinity of $15 \mathrm{psu}$ in our experiment suggests that the optimum salinity of osmoregulation in the Baltic herring is higher than the salinity where fish live in nature. Interestingly, Holliday and Blaxter (1961) found that Atlantic herring, which lives in oceanic salinities ( $>30 \mathrm{psu}$ ) recovered from the handling stress and loss of scales best in salinity of $<15.8 \mathrm{psu}$. In this salinity, sea water was isotonic with the herring blood (Holliday and Blaxter 1961). It is not known, however, whether the same value applies to the Baltic herring, too.

Fish growth is controlled by several external factors of which temperature and food are traditionally considered as the major ones (e.g., Weatherley and Rogers 1978). Also oxygen can influence the growth of fish, and probably the scale growth as well (Ottaway and Simkiss 1977). However, hypoxia usually becomes visible as a change of fish behaviour; i.e., fish loose their activity, stay close to the water surface and even tend to breathe air (Kramer 1987).
Such effects were not observed in our experiments, although the condition of fish was checked daily. Moreover, the oxygen saturation level in the test tanks was regularly controlled and it proved to be high in all tanks through the experiment. With exception of salinity, the environmental conditions and treatment of fish were similar in all tanks and consequently, the observed differences in mortality, accumulation of fat, fish condition and growth rate were most likely due to the salinity.

In the Archipelago Sea, herring are known to feed still in December (Rajasilta 1992) so that the experimental conditions matched relatively well the feeding cycle of the herring in their natural environment. Somatic growth of herring, instead, takes place mainly in summer and autumn, so that the time of the experiment was not optimal with regard to herring growth in the sea. Additional light with a photoperiod of $12 \mathrm{~h}$ light: $12 \mathrm{~h}$ dark apparently corrected this problem sufficiently, as fish were feeding and some growth took place in all salinities, but water temperature $\left(+6^{\circ} \mathrm{C}\right)$ was obviously too low for rapid growth. The mean length and weight of fish increased with increasing salinity (Fig. 4), but as fish size was not determined in the beginning of the experiment, in order to avoid stress-induced mortality, the potential differences in growth cannot be asserted using length and weight data.

Many studies have shown that salinity affects euryhaline fish in multiple ways; e.g., their behaviour, intake of food, food conversion rate, somatic condition, fat reserves, growth and survival (e.g., Peterson-Curtis 1997; Boeuf et al. 1999; Peterson et al. 1999; Atwood et al. 2001; Jarvis et al. 2001; Cordier et al. 2002). Euryhaline species usually tolerate a wide range of salinities as adults, but they have a given optimum, where they perform best growth. In clupeids, the effect of salinity on growth has been studied with juvenile Atlantic menhaden, Brevoortia tyrannus. In experimental conditions, this species achieved better growth in salinity of 5-10 ppt than in 28-34 ppt, where adult live (Hettler 1976). In marine turbot, Scophthalmus maximus, brackish water (8-20 psu) enhanced somatic growth (Boeuf et al. 1999), whereas in juvenile sturgeon, Acipenser brevirostrum, the growth rate was highest in fresh water.

Fish growth is a complicated physiological process, where several hormones are involved (Holloway and Leatherland 1998; Mommsen 2001). It is possible that salinity affects directly on growth, by stimulating the endocrinological system, which regulates the production of growth hormone and other growth promoting substances such as the insulin-like growth factors. These, in turn, can have an effect on the osmoregulatory capacity of fish (Seidelin et al. 1999; Inoue et al. 2003). Growth hormone, for instance, increases the tolerance for non-optimal salinites in fish (Sakamoto and McCormick 2006). 
Alternatively, faster growth can be a result of decreased costs of osmoregulation (Hettler 1976; Imsland et al. 2003). For instance in turbot, growth was improved when fish were reared in water that was isoosmotic to fish blood (Gaumet et al. 1995; Imsland et al. 2003). In our study, a direct effect of salinity on growth was obvious, although this effect may well have been strengthened by lower costs of osmoregulation in the higher salinities.

In estuarine nursery grounds, where salinity may vary considerably during the growth season, fish juveniles seek for such salinities that enhance their growth (Lankford and Targett 1994). In most of the Baltic Sea, salinity is constantly low at such depths where herring juveniles live (Raid 1985; Urho and Hildén 1990; Axenrot and Hansson 2004) so that they cannot find a higher salinity even though it would provide them better growth. However, from the nursery grounds of the south-western Baltic, which are close to the Danish straits, the Baltic herring migrate out to the Skagerrak and Kattegat area (Jönsson and Biester 1981; Aro 1989), where salinity is $15-20$ psu (Fig. 1). The southwestern herring populations exhibit high growth rate and large body size (Popiel 1958) obtained in a higher salinity compared to that in the Baltic Sea, with the exception of the deep bottom areas. This example from field conditions thus supports our results and suggests that the optimum salinity for the Baltic herring growth is somewhat higher than the present salinity of the Baltic Sea; possibly within 8-12 psu.

Present herring juveniles were about 5 months old when starting the experiment. At this phase, herring juveniles already resemble adults by their general physiology (Blaxter and Holliday 1963). Our results can thus represent also the adult Baltic herring, but this is not necessarily so. In adult fish, excretion of sexual hormones can modulate the action of the hormones that control growth and osmoregulation (Holloway and Leatherland 1998). Therefore, more studies are needed to find out the optimum salinity of the Baltic herring in different phases of its life cycle. Our study demonstrates that although experimental work with the Baltic herring faces difficulties due to sensitivity of the species to handling and life in captivity, the effect of stress can be reduced by increasing water salinity to $12-15 \mathrm{psu}$. In such conditions, it could be possible to carry out the experiments with replicates and other arrangements meeting the requirements of normal experimental design, which we failed to do in the present work.

Acknowledgments The authors thank Rauno Rinne, who assisted in the daily routines of the experiments, Olle Lerche for providing the facilities at the Finnish Institute of Fisheries and Environment and the anonymous referees for the constructive comments on the manuscript. The study was partly financed by the EU (project No 96-068).

\section{References}

Adelman IR (1987) Uptake of radioactive amino acids as indices of current growth rate of fish: a review. In: Summerfelt RC, Hall GE (eds) The age and growth of fish. Iowa State University Press, Ames, pp 65-79

Aro E (1989) A review of fish migration patterns in the Baltic. Rapp P-v Réun Cons Int Explor Mer 190:72-96

Atwood HL, Young SP, Tomasso JR, Smith TIJ (2001) Salinity and temperature tolerances of Black Sea bass juveniles. N Am J Aquacult 63:285-288

Axenrot T, Hansson S (2004) Seasonal dynamics in pelagic fish abundance in a Baltic Sea coastal area. Est Coast Shelf Sci 60:541-547

Bekkevold D, André C, Dahlgren TG, Clausen LAW, Torstensen E, Mosegaard H, Carvalho G, Chistensen TB, Norlinder E, Ruzzante DE (2005) Environmental correlates of population differentiation in Atlantic herring. Evolution 59:2656-2668

Blaxter JHS, Holliday FGT (1963) The behaviour and physiology of herring and other clupeids. Adv Mar Biol 1:261-393

Boeuf G, Boujard D, Person-Le Ruyet J (1999) Control of the somatic growth in turbot. J Fish Biol 55(Suppl A):128-147

Busacker GP, Adelman IR (1987) Uptake of ${ }^{14} \mathrm{C}$-glycine by fish scales (in vitro) as an index of current growth rate. In: Summerfelt RC, Hall GE (eds) The age and growth of fish. Iowa State University Press, Ames, pp 355-357

Cordier M, Brichon G, Weber J-M, Zwingelstein G (2002) Changes in the fatty acid composition of phospholipids in tissues of farmed sea bass (Dicentrarchus labrax) during an annual cycle. Roles of environmental temperature and salinity. Comp Biochem Physiol B 133:282-288

Eklund J (1999) Herring growth and age estimates from otolith and scales. Study report, Archipelago Research Institute, University of Turku, Turku $4 \mathrm{pp}$

Evans DH (1980) Kinetic studies of ion transport by fish gill epithelium. Am J Physiol 238:224-230

Evans DH (1993) Osmotic and ionic regulation. In: Evans DH (ed) The physiology of fishes. CRC Press Inc, Boca Raton, pp 315341

Fonselius S, Valderrama J (2003) One hundred years of hydrographic measurements in the Baltic Sea. J Sea Res 49:229-241

Gaumet F, Boeuf G, Severe A, Le Roux A, Mayer-Gostan N (1995) Effects of salinity on the ionic balance and growth of juvenile turbot. J Fish Biol 47:865-876

Goolish EM, Adelman IR (1983) Effects of fish growth rate, acclimation temperature and incubation temperature on in vitro glycine uptake by fish scales. Comp Biochem Physiol 76A:127134

Griffin FJ, Pillai MC, Vines CA, Kääriä J, Hibbard-Robbins T, Yanagimach R, Cherr GN (1998) Effects of salinity on sperm motility, fertilization and development in the Pacific herring, Clupea pallasi. Biol Bull 194:25-35

Haegele CW, Schweigert JF (1985) Distribution and characteristics of herring spawning grounds and description of spawning behaviour. Can J Fish Aquat Sci 42(Suppl 1):39-55

Hettler WF (1976) Influence of temperature and salinity on routine metabolic rate and growth of young Atlantic menhaden. J Fish Biol 8:5555-5565

Hognestad PT (1994) The Lake Rossfjord herring (Clupea harengus L.) and its environment. ICES J Mar Sci 51:281-292

Holliday FGT, Blaxter JHS (1961) The effects of salinity on herring after metamorphosis. Mar biol Ass UK 41:37-48

Holloway AC, Leatherland JF (1998) Neuroendocrine regulation of growth hormone secretion in teleost fishes with emphasis on the 
involvement of gonadal sex steroids. Rev Fish Biol Fish 8:409_ 429

ICES (2008) Report of the ICES advisory committee, 2008. ICES Advise, 2008. Book 8, $133 \mathrm{pp}$

Imsland AK, Foss A, Gunnarsson S, Berntssen MHG, FitzGerald R, Bonga SW, v Ham E, Naevdal G, Stefansson SO (2001) The interaction of temperature and salinity on growth and food conversion in juvenile turbot (Scophthalmus maximus). Aquaculture 198:353-367

Imsland AK, Gunnarsson S, Foss A, Stefansson SO (2003) Gill $\mathrm{Na}^{+}$, $\mathrm{K}^{+}$-ATPase activity, plasma chloride and osmolality in juvenile turbot (Scophthalmus maximus) reared at different temperatures and salinities. Aquaculture 218:671-683

Inoue K, Iwatani H, Takei Y (2003) Growth hormone and insulin-like growth factor I of a euryhaline fish Cottus kazika:cDNA cloning and expression after seawater acclimation. Gen Comp Endocrinol 131:77-84

Jarvis PL, Ballantyne JS, Hogans WE (2001) The influence of salinity on the growth of juvenile shortnose sturgeon. $\mathrm{N}$ Am J Aquacult 63:272-276

Jönsson N, Biester E (1981) Wanderbewegungen des Rügenschen Frühjahrsherings in den Küsten- und Boddengewässern der DDR. Fischerei-Forschung 19:47-51

Jörgensen HBH, Hansen MM, Bekkevold D, Ruzzante DE, Loeschke V (2005) Marine landscapes and population genetic structure of herring (Clupea harengus L.) in the Baltic Sea. Mol Ecol 14:3219-3234

Kapoor BG, Khanna B (2004) Ichthyology handbook. Springer, Berlin $1059 \mathrm{pp}$

Klinkhardt M (1984) Zum Einfluss des Salzgehaltes auf die Befruchtungsfähigkeit des Laichen der Rügenschen Frühjahrsheringe. Fisherei-Forschung 22:73-75

Kramer DL (1987) Dissolved oxygen and fish behaviour. Env Biol Fish 18:81-92

Lankford TE Jr, Targett TE (1994) Suitability of estuarine nursery zones for juvenile weakfish (Cynoscion regalis): effects of temperature and salinity on feeding, growth and survival. Mar Biol 119:611-620

Mommsen TP (2001) Paradigms of growth in fish. Comp Biochem Physiol B 129:207-219

Neb K-E (1970) Über die Heringe des Windebyer Noors. Ber Dt Wiss Komm Meeresforsch 21:265-270

Negatu Z, Meier AH (1993) Daily variation of protein synthesis in several tissues of the Gulf gillifish, Fundulus grandis Baird and Girard. Comp Biochem Physiol 106A:251-255

Negatu Z, Meier AH (1995) In vitro incorporation of $\left[{ }^{14} \mathrm{C}\right]$ glycine into muscle protein of gulf killifish (Fundulus grandis) in response to insulin-like growth factor-I. Gen Comp Endocrinol 98:193-201
Ojaveer E (1981) Influence of temperature, salinity, and reproductive mixing of Baltic herring groups on its embryonal development. Rapp P-v Réun Cons int Explor Mer 178:409-415

Ottaway EM (1978) Rhythmic growth activity in fish scales. J Fish Biol 12:615-623

Ottaway EM, Simkiss K (1977) Instantaneous growth rates of fish scales and their use in studies of fish populations. J Zool Lond 181:407-419

Parmanne R, Rechlin O, Sjöstrand B (1994) Status and future of herring and sprat stocks in the Baltic Sea. Dana 10:29-59

Peterson MS, Comyns BH, Rakocinsky CF, Fulling GL (1999) Does salinity affect somatic growth in early juvenile Atlantic croaker, Micropogonias undulates (L.)? J Exp Mar Biol Ecol 238:1999_ 2007

Peterson-Curtis TL (1997) Effects of salinity on survival, growth, metabolism, and behavior in juvenile hogchokers, Trinectes maculatus fasciatus (Achiridae). Env Biol Fish 49:323-331

Popiel J (1958) Differentiation of the biological groups of herring in the southern Baltic. Rapp P-V Réun Cons Int Explor Mer 143:114-121

Raid T (1985) The reproduction areas and ecology of Baltic herring in the early stages of development found in the Soviet zone of the Gulf of Finland. Finnish Fish Res 6:20-40

Rajasilta M (1992) Relationship between food, fat, sexual maturation and spawning time of Baltic herring (Clupea harengus membras) in the Archipelago Sea. Can J Fish Aquat Sci 49:644-654

Rudstam LG, Aneer G, Hildén M (1994) Top-down control in the pelagic Baltic ecosystem. Dana 10:105-129

Sakamoto T, McCormick SD (2006) Prolactin and growth hormone in fish osmoregulation. Gen Comp Endocrinol 147:24-30

Segerstråle SG (1957) Baltic Sea. In: Hedgpeth JW (ed) Treatise on marine ecology and paleology. Geol Soc Am Mem 67:751-800

Seidelin M, Mades SS, Byrialsen A, Kristiansen K (1999) Effects of insulin-like growth factor-I and cortisol on $\mathrm{Na}+, \mathrm{K}+$-ATP-ase expression in osmoregulatory tissues of brown trout (Salmo trutta). Gen Comp Endocrinol 113:331-342

SPSS Inc (2005) SPSS 14.0 for Windows

Tesch FW (1971) Age and growth. In: Ricker WE (ed) Methods for assessment of fish production in fresh water. IBP handbook No 3. Blackwell Scientific Publications, Oxford, pp 98-126

Urho L, Hildén M (1990) Distribution patterns of Baltic herring larvae, Clupea harengus L., in the coastal waters off Helsinki, Finland. J Plankton Res 12:41-54

Weatherley AH, Rogers SC (1978) Some aspects of age and growth. In: Gerking SD (ed) Ecology of freshwater fish production. Blackwell Scientific Publications, London, pp 52-74

Westin L, Aneer G (1987) Locomotor activity patterns of nineteen fish and five crustacean species from the Baltic Sea. Env Biol Fish 20:49-65 